\title{
CONTINUOUS CASE STUDY AS AN EFFECTIVE METHOD OF ENGLISH LANGUAGE LEARNING BY FUTURE ENGINEERS
}

\section{Kateryna Halatsyn}

Ph.D., Associate Professor, Associate Professor at the Department of English for Engineering № 2, National Technical University of Ukraine

"Igor Sikorsky Kyiv Polytechnic Institute", Ukraine e-mail: galatsyn_kateryna@ukr.net, orcid.org/0000-0003-3297-8284

\section{Alla Feshchuk}

Lecturer at the Department of English for Engineering № 2, National Technical University of Ukraine "Igor Sikorsky Kyiv Polytechnic Institute", Ukraine e-mail: fam2012@ukr.net, orcid.org/0000-0003-3683-099X

\section{Andrii Galaidin}

Ph.D. student, Polonia University in Czestochowa, Interdisciplinary Faculty, Poland e-mail: a.galaidin@ap.edu.pl,orcid.org/0000-0002-5236-1495

\section{Summary}

The present paper addresses the issue of teaching foreign language as an indispensable course at university. One of the demands to the training of future engineers is to prepare them for solving professional tasks and situations. A continuous case study method is one of the forms of problem-based learning which allows teachers to model fragments of future professional activity, its multicultural context. We suggest a continuous case study method as a powerful tool for modelling real professional activities, which contributes to the formation of professionally oriented English-language competence of future engineers. In our article, we aim to reveal the essence and stages of using the method of continuous case studies at English classes. We outlined the following methods: analysis, synthesis, generalization, systematization, inference, observation. In order to verify our statement, we conducted a continuous case study on the topic "Refutation of inaccurate information on technical operation and repair of lifting mechanisms at the enterprise". As shown by the results of our research, a continuous case study method is a way of development of a professionally oriented English-language competence of the future engineers by involving them in solving imaginary professionally oriented problems through simulated engineering environment. It has been found that the use of a continuous case study method in the course "Practical Course of Foreign Language for Professional (Scientific) Purposes" contributes to the improvement of the future engineers' professionally oriented foreign-language competencies in listening, speaking, reading; professionally oriented sociocultural, linguistic, educational, strategic and pragmatic competencies.

Keywords: professionally oriented foreign-language competencies, the educational process, case method, future engineers, interaction, communication, English-language classes.

DOI: https://doi.org/10.23856/4210

\section{Introduction}

Nowadays in the period of intensive development of modern society and integration of Ukraine into the European community, fluent and accurate knowledge of English is 
professionally necessary for engineering specialists. This implies that new demands for the domestic system of higher education and the personal and professional qualities of students are indispensable. In this regard, it is important to understand that in order to train future engineers effectively, it is necessary to create circumstances close to foreign language professional communication by modeling the most typical professional situations at English language classes. All this is possible by using the method of case study as a simulated model of professional activity of an engineer at English language classes.

It is worth noting that unlike other teaching methods case studies differ in allowing students "to live" a certain professional role in a certain professional environment. By virtue of dichogamy, this teaching method allows us to model fragments of future professional activity, its multicultural context; act parts of different behaviors in the professional sphere, analyze and correct them. As well as, case study provides positive emotional impact on students, activates their backup opportunities.

The relevance of the outlined problem is determined by the fact that the use of case studies in the formation of English language competence of future engineers is effective inasmuch as:

- the application of case studies in the educational process of future engineers is brought to real practical activities to the possible extent;

- case studies are considered to be an interactive simulation teaching method, in which participants act in different roles and make decisions in accordance with the interests of their role;

- case studies allow all participants of collective interaction to communicate, express, prove their own opinions and judgments;

- case studies contribute to the creation of a positive emotional atmosphere among students, demonstration of their individuality.

It should be emphasized that game theory, structure and significance of the game in the educational process were studied by psychologists D. Elkonin, O. Leontiev, L. Vygotsky; educators A. Prutchenkov, O. Rivin, V. Rozov, G. Selevko, I. Shvedova, L. Stefan, A. Verbytsky and others.

The role of games in the process of foreign language teaching is analyzed by Yu. Gapon, L. Kotliarova, T. Pankiv, E. Passov, T. Sviridiuk, and others. The specifics of using case studies on English language classes are studied by Yu. Haidenko, N. Yaremenko and others. The researches of T. Besarab and L. Rusalkina are devoted to the problem of using continuous case studies.

Since our main research questions are of explanatory (how) and mediating nature we decided to carry out our research in the framework of the analysis of the experience of foreign language teachers in higher technical educations which allows us to outline the relevance of using case studies as an interactive technology and emphasize that higher technical education institutions in Ukraine lack sufficient understanding of the importance and possibilities of using continuous case studies at English language classes.

In our article, we aim to reveal the essence and stages of using the method of case studies at English classes in higher technical education institutions. The implementation of mentioned aim is possible in performing the following tasks: 1) substantiate essence and stages of a case study; 2) determine the benefits of using a continuous case study at English classes in higher technical education institutions.

In the process of scientific research, we outlined the following methods: analysis, synthesis, generalization, systematization, inference, observation. 


\section{Results}

Training of qualified engineering specialists capable of competent and effective English-language communication in the technical field at the level of European and world standards requires the use of the teaching methods aimed at bringing the educational process closer to real professional situations. In this regard, the method of case study is gaining primary importance.

Halatsyn and Khomiak (2019) define case study as a simulation modeling of the processes of educational reality and game modeling of students' professional activity, which is carried out in simulated situations and associated with the management of the educational process (p. 16). Shtefan (2011), along with the case study, introduces the concept of "managing case studies" and defines them as a kind of games of the production sphere that model management situations and take place in production (p. 115). Based on the specifics of professional training of engineers, it can be a shipyard, missile producing plant, power plant, machine building, etc. In view of modeling of dyad relationships, the following options are possible: director - engineer, foreman - engineer; deputy of foreman - engineer; production supervisor - engineer; engineer - worker, etc. In this context, the list can be extended further, taking into account that each of the dyads becomes the basis for playing a certain game situation. It is obvious that educational case studies are a synthesis of relaxopedic approaches and a number of simulated problem situations, including conflict, in which participants perform certain social roles in accordance with the goals (Rusalkina, 2015).

At present we are dealing with such an innovative method which is widely implemented in the educational process as continuous case study. According to Besarab (2013), continuous case study is "a specific organization of work in the course of Business English, during which training is developed as a constant modeling and reproduction of business activity in the classroom" (p. 667). In line with Besarab's (2013) definition, Rusalkina (2015) elaborates the given definition, emphasizing that "continuous case study, in contrast to traditional case studies, combines the entire educational process into a single plot for all educational and communicative activities" (p. 121).

Our analysis of the characteristics of the concepts of "case study" and "continuous case study" allows us to identify the method of continuous case study as a way of formation of professionally oriented English language competence by involving future engineers in solving imaginary vocationally oriented problems in simulated engineering environment. This implies that such activities combine the whole educational process into a single plot of educational and communicative activities, which develops in a continuous case study from lesson to lesson; the only characters of this game create an imaginary life continuum in which students improve both Business English and the competences of future professional activity, imitating or modeling the business environment (Shtefan, 2011: 121).

From this definition of a continuous case study, it follows that the problem of content in a continuous case study consists in solving a certain vocationally oriented task, which involves several possible ways to work it out. In this context the use of creative tasks, solving situational problems, creating projects, organizing thematic conversations in the classroom should precede the game and provide its implementation in education process.

The experience of using a continuous case study in the process of learning English suggests that we can apply it at a particular stage of each lesson or in the final course after studying a separate topic/section in English.

In order to summarise the competencies to prepare and produce business and professional correspondence during the study of the topic "Incidents" we conducted a continuous case 
study "Refutation of inaccurate information on technical operation and repair of lifting mechanisms at the enterprise". During the continuous case study, students participate in the discussion of situations, to illuminate false information about theft in the warehouse and analyse possible options for refuting it. During the game, the future engineers fix the following competencies in Listening: Using modal forms - the use of modal verbs in professional English vocabulary; Reading: A theft at a warehouse - the ability to conduct a dialogue on this topic; Speaking: Questioning about the numbered items - improvement of the ability to audit numbered items (Haidenko, 2016: 125). In this case, we use a continuous case study at different stages of the lesson, summarising competencies in speaking, translation, dialogue, working with texts and the like.

In the process of learning the topic "Incidents" which covers six subtopics (Incidents. Theft; Incidents. Security; Incidents. Emergency; Accidents. Investigations; Accidents. Report; Accidents. Communication) in each class during the generalization and systematization, we use a straight case study method "Enterprise Problem/Incident Resolution" (Haidenko, 2016: 125). When playing a part of professional roles as engineers of various enterprises, students try to find ways of solving a professional problem. For example, in the course of this topic, we conduct a continuous case study "Mechanical engineering industry in Ukraine" during these classes.

Accordingly, we emphasise that a continuous case study on the outlined topics is extremely relevant, since engineering is one of the priority sectors of the world economy, which is dynamically developing. Ukraine, as an industrial country, has the prerequisites to become one of the world leaders in the engineering industry. A significant number of engineering enterprises operate in the country, constituting a holistic production sector of the economy, which has a specific infrastructure. In a recent paper by Borshch (2010) mechanical engineering industry of Ukraine is characterised as science-intensive, for which it is natural to increase the technical and technological level of production, constant complication of products, production technologies and methods of its organisation. Therefore, by considering and analysing the problems of mechanical engineering, future engineers act as various specialists, namely: design engineer, processing engineer, hoisting apparatus engineer, civil engineer, mechanisation engineer of labour-intensive processes, mechanisation and automation engineer of production processes, accident prevention officer, equipment configuration engineer, production engineer, labour rationing engineer, standardisation engineer, quality engineer, maintenance engineer, engineer for the introduction of new equipment and technologies.

In the course of a continuous case study, students have the opportunity to provide a real exchange of professional knowledge, offer their ways to solve the problem of the mechanical engineering industry in order to bring it to a qualitatively new level. The creative group work of future engineers during the game contributes to the unification of their efforts, the vita of the gene experience of students, their creative potential for joint actions aimed at the optimal solution of the problem. In such activities, young people feel complete freedom of creativity in expressing their views and arguments in English, without fear of being misjudged by a teacher. A favourable emotional environment becomes a free playing space in which students feel "free, since they regulate the rules operating within this space". As a rule, a continuous case study method during the generalization of the topic can take up to $60 \%$ of the study time.

Thus, it is obvious that creating professional situations for a continuous case study, the teacher draws attention to the fact that the tasks reflect the real situations of engineering activities and submit the problem from an unexpected angle. In the course of a continuous case study, students have the opportunity to express their views on solving the problem of future 
professional activity, discuss, prove the truth or refute the lie of their judgment. That, in turn, promotes the creative self-expression of each subject of educational interaction.

It is worth noting that each of the topics at the English language classes provides for either the formation of a holistic system of competencies mentioned in the curriculum of the course "Practical Course of Foreign Language for Professional (Scientific) Purposes" or individual competencies in speaking, listening, translation, etc. (Haidenko, 2016).

However, in order to make a continuous case study efficient, we adhered to the following principles:

- game modelling of content and forms of professional activity. The implementation of this principle is a prerequisite for a continuous case study, since it realizes educational functions;

- joint activities. It is mandatory to attract several participants to cognitive activities in a continuous case study. The requirements of this principle will demand of the teacher to choose and characterize roles; determine their authority, interests and means of activity. At the same time, the most characteristic types of professional engineering interaction of "officials" are identified and modelled;

- dialogic communication. The dialogue organized during a continuous case study, the discussion on the maximum participation of all participants contributes not only to the improvement of professional English language vocabulary, but also develops the creative imagination and creative abilities of each subject of the game. Comprehensive collective discussion of educational material allows students to achieve a comprehensive presentation of professionally significant processes and activities;

- the principle of bipartite reflects the process of developing the real personal characteristics of a specialist in "imaginary" playing conditions. The teacher aims to realize bilateral goals that reflect the real and playing contexts of educational activities;

- the problematics of the content of the simulation model and the process of its discovery in the gaming activity (Shtefan, 2011).

Thus, the use of a continuous case study at English language classes required us to follow such steps (Myroliubov, 2010):

- diagnostic - justified the need to use a continuous case study at the lesson in reference to the selected content (importance, problem, practical significance), level of students' training (independence in analysis and solving problems, ability to show initiative, creativity, interaction in groups), readiness of the teacher (ability to organize, conduct and manage the game);

- planning of a continuous case study - provides for determining the place of the game in the educational process according to the formulated goal (at what stage of the lesson or complex of classes it is advisable to use a continuous case study and what English-speaking competencies it will contribute to the formation of), the game design (problem content and formulation of the educational problem / set of problems to create the game conflict), selection of useful techniques for effective implementation of the game (conversation, discussion, exercises, moderation, drawing tree, etc.);

- holding a continuous case study - includes problem definition and purposes of a game, development of general criteria for evaluation of the educational and game interactions, determination of the ways of the quality assessment decisions: submit decisions to the specified term, interaction among participants (interaction of participants within game groups, personal traits of participants), reflection (p. 346-348).

In our article, based on the practical experience of English language teaching, we outlined the effective conditions of implementing a continuous case study method in English language learning process of future engineers: 
- designation of a lesson stage (or lesson cycle) at which a continuous case study method is implemented;

- presence of clear aims of the specified lesson stage as a part of the didactic goal;

- relevance of a problem for the continuous case study, its practical and educational potential;

- dynamic nature of reality reproduction (during a continuous case study participants treat the task as a real problem);

- systematic character, continuity, and preliminary planning of a didactic continuous case study (participants should have time to get to know the topic of the game and prepare for it);

- predicting and selecting enough exercises to train particular skills;

- a clear focus of a continuous case study on formation, consolidation or generalization of English-language professional vocabulary and competencies of professional activity;

- focus on achieving the success in a continuous case study through the thorough training of its participants, forming the skills of friendly rivalry, publicity, manageability on the part of a teacher;

- relevance, motivation and personal significance of a continuous case study for each of its participants.

\section{Conclusions}

As shown by the results of our research, we find a continuous case study method the most effective for modelling the real business activity, which contributes to the formation of professionally oriented English-language competence of future engineers, while imitating the activities they will to do in real professional communication. In the course of a scientific search, a continuous case study method is defined as a way of development of a professionally oriented English-language competence of the future engineers by involving them in solving imaginary professionally oriented problems through simulated engineering environment. Our research confirms that this type of an educational game covers a holistic educational process at English language classes with a single plot, which develops in a continuous case study from class to class. It has been found that the use of a continuous case study method in the course "Practical Course of Foreign Language for Professional (Scientific) Purposes" contributes to the improvement of the future engineers' professionally oriented foreign-language competencies in listening, speaking, reading; professionally oriented sociocultural, linguistic, educational, strategic and pragmatic competencies. Along with this, the use of a continuous case study develops the communicative skills, creative and original thinking of future engineers.

\section{References}

Besarab T.P. (2013). Ispolzovanie kommunikativnoj metodiki v prepodavanii anglijskogo yazyka (na primere kursov intensivnogo izucheniya anglijskogo $v$ Velikobritanii) [The use of communicative methods in teaching English (on the example of intensive English courses in the UK)]. Chita: Molodoj uchenyj. [in Russian]

Verbickij A. A. (2010) Pedagogicheskie tehnologii kontekstnogo obucheniya : nauchno-metodicheskoe posobie [Pedagogical technologies of contextual learning: scientific and methodological manual]. Moskva: RIC MGGU im. M. A. Sholohova. [in Russian] 
Vorovka M.I. (2007) Dilova hra yak zasib pidhotovky maibutnikh uchyteliv do profesiinoi diialnosti [Continuous case study as a means of preparing future teachers for professional activity:]. Extended abstract of candidate's thesis. Ternopil [in Ukrainian]

Halatsyn K.O., Khomiak A.P. (2019) Interaktyvni tekhnolohii formuvannia komunikatyvnoi kultury maibutnikh fakhivtsiv na zaniattiakh $z$ anhliiskoi movy: navch. posib. [Interactive technologies of formation the communicative culture of the future specialists in English language classes]. Lutsk: Vezha-Druk. [in Ukrainian]

Haidenko Yu. O. (2016) Metodychni rekomendatsii do orhanizatsii ta provedennia dilovykh ihor na zaniattiakh z inozemnoi movy u tekhnichnykh universytetakh [Methodical recommendations to organize and conduct the continuous case study in foreign language classes at technical universities]. Kyiv: NTUU «KPI». [in Ukrainian]

Mirolyubov A.A. (2010) Sovremennye pedagogicheskie tehnologii. Metodika obucheniya inostrannym yazykam: tradicii i sovremennost [Modern pedagogical technologies. Methods of teaching foreign languages: traditions and modernity]. Obninsk: Titul. [in Russian]

Rusalkina L.H. (2015) Vykorystannia dilovykh i rolovykh ihor u protsesi navchannia inozemnoi movy studentiv medychnykh VNZ. Vykladannia mov u vyshchykh navchalnykh zakladakh osvity. [The use of a case study in the process of teaching medical students a foreign language]. Language teaching in higher educational institutions, no. 26, pp. 119-127. Retrived from: https:// periodicals.karazin.ua/language_teaching/article/view/2840_in Ukrainian]

Shtefan L. (2011) Dilova hra yak odyn iz zasobiv formuvannia innovatsiinoi kultury inzhenera-pedahoha [Case study as one of the means of forming an innovative culture of an engineer-teacher]. Molod i rynok - Youth and market, no. 1, pp. 114-119. Retrived from: http:// nbuv.gov.ua/UJRN/Mir_2011_1_26 [in Ukrainian] 